Mansour et al., Afr J Tradit Complement Altern Med., (2017) 14 (4): 108-119

https://doi.org/10.21010/ajtcam.v14i4.13

\title{
PROTECTIVE EFFECT OF CAMEL MILK AS ANTI-DIABETIC SUPPLEMENT: BIOCHEMICAL, MOLECULAR AND IMMUNOHISTOCHEMICAL STUDY
}

\author{
Ahmed A. Mansour ${ }^{1,2 *}$, Mohammed A. Nassan³, Osama M. Saleh", ${ }^{1,4}$ Mohamed M. Soliman ${ }^{5,6}$ \\ ${ }^{1}$ Medical Biotechnology Department, Faculty of Applied Medical Sciences (Turbah), Taif Univ., KSA. \\ ${ }^{2}$ Genetics Department, Faculty of Agriculture, Ain Shams University, Cairo, Egypt. ${ }^{3}$ Pathology Department, \\ Faculty of Veterinary Medicine, Zagazig University, Zagazig, Egypt. ${ }^{4}$ National Centre for Radiation Research \\ and Technology (NCRRT), Egyptian Atomic Energy Authority (EAEA), Nasr City, Cairo, Egypt. ${ }^{5}$ Biochemistry \\ Department, Faculty of Veterinary Medicine, Banha University, Banha, Egypt. ${ }^{6}$ Medical Laboratories \\ Department, Faculty of Applied Medical Sciences (Turbah), Taif University., KSA.
}

*Corresponding Author E-mail: Ahmedmansour292@gmail.com

\begin{abstract}
Background: Diabetes is a serious disease affects human health. Diabetes in advanced stages is accompanied by general weakness and alteration in fats and carbohydrates metabolism. Recently there are some scientific trends about the usage of camel milk (CM) in the treatment of diabetes and its associated alterations. CM contains vital active particles with insulin like action that cure diabetes and its complications but how these effects occur, still unclear.

Materials and Methods: Seventy-five adult male rats of the albino type divided into five equal groups. Group 1 served as a negative control (C). Group 2 was supplemented with camel milk (CM). Diabetes was induced in the remaining groups (3, 4 and 5). Group 3 served as positive diabetic control (D). Group 4 served as diabetic and administered metformin (D+MET). Group 5 served as diabetes and supplemented with camel milk (D+CM). Camel milk was supplemented for two consecutive months. Serum glucose, leptin, insulin, liver, kidney, antioxidants, MDA and lipid profiles were assayed. Tissues from liver and adipose tissues were examined using RT-PCR analysis for the changes in mRNA expression of genes of carbohydrates and lipid metabolism. Pancreas and liver were used for immunohistochemical examination using specific antibodies.

Results: Camel milk supplementation ameliorated serum biochemical measurements that altered after diabetes induction. $\mathrm{CM}$ supplementation up-regulated mRNA expression of $I R S-2, P K$, and $F A S N$ genes, while down-regulated the expression of $C P T-1$ to control mRNA expression level. CM did not affect the expression of PEPCK gene. On the other hand, metformin failed to reduce the expression of $C P T-1$ compared to camel milk administered rats. Immunohistochemical findings revealed that CM administration restored the immunostaining reactivity of insulin and GLUT-4 in the pancreas of diabetic rats.

Conclusion: CM administration is of medical importance and helps physicians in the treatment of diabetes mellitus.
\end{abstract}

Keywords: Camel milk, Diabetes, Gene expression, Immunohistochemistry.

Abbreviations: STZ: Streptozotocin; MET: metformin; CM: Camel milk; GLUT4: glucose transporter4; FASN: fatty acid synthases; CPT-I: carnitine palmitoyl transferase I; PEPCK: phosphoenolpyruvate carboxykinase; PK: pyruvate kinase; IRS-2: Insulin receptor substrate 2; GAPDH: glyceraldehyde-3-phosphate dehydrogenase; T1D: type-1-diabetes; T2D: type-2-diabetes; TC: total cholesterol; TG: triglycerides; HDL: high-density lipoproteins; CAT: catalase; GR: glutathione reductase; SOD: superoxide dismutase; MDA: malondialdehyde; GPT: glutamic-pyruvic transaminases; GOT: glutamic-oxalacetic transaminases; PBS: phosphate-buffer saline.

\section{Introduction}

Diabetes mellitus type 1 (T1D) is a complex disease resulting from the interplay of genetic, endocrine, epigenetic, and environmental factors (Hakonarson and Grant 2011). Worldwide, the T1D represents an increasing global public health burden, and the incidence of T1D among humans has been rising (Forlenza and Rewers 2011). Over the last few decades, there has been an overall increase in the incidence of T1D of $\sim 3 \%$ to $5 \%$ per year, and it is estimated that there are $~ 65000$ new cases per year in children, 15 years old (Borchers et al 2010). Moreover, the number of peoples with diabetes will rise to 500 million within the next 20 years (Malik et al 2012). Africa will experience a largest increase in the next generation 108 


\section{Mansour et al., Afr J Tradit Complement Altern Med., (2017) 14 (4): 108-119 \\ https://doi.org/10.21010/ajtcam.v14i4.13}

for diabetes incidence. But till now Middle East is characterized with high incidence of diabetes but Africa still the most affected (Al-Baghli et al 2011).

Failure to control insulin level in our bodies is the leading cause of diabetes. Only 5\%-10\% of diabetic patients do not produce insulin because of complete destruction in pancreatic $\beta$-cells that results in hyperglycemia and ketoacidosis in type-1 diabetic patients (Gaba et al 2015). Type 2 diabetes (T2D), a non-insulin-dependent diabetes mellitus, is associated with insulin resistance as cells of the body can't respond to insulin. Accidental drug treatments such as glucocorticoids, $\beta$ adrenergic agonists, statins, Streptozotocin (STZ), and alloxan induce diabetes. STZ and alloxan are used to induce diabetes in rodent lab animal models (Eleazu et al 2013). The pancreatic $\beta$-cells take up the STZ via the plasma membrane GLUT2 transporter2, resulting in inflates, and ultimately irreversible destroys the pancreatic $\beta$-cells (Eleazu et al 2013; Ikebukuro et al 2002; Akbarzadeh et al 2007; Muhammad and Syed 2010; Sboui et al 2010; Sharma et al 2012). STZ treatment induces T1D (Muhammad and Syed 2010), and may induce T2D (Arulmozhi et al 2004; Martha et al 2009).

Camel milk has valuable therapeutic effects on treatment of wounds as it enhance wound healing and increase immune cell proliferation and chemotaxis state of experimental animals (Badr 2012 and 2013; Badr et al 2011 and 2012). Presence of peptides and proteins in camel's milk are the cause of its biological in digestion, absorption, growth and immunity (Korhonen and Pihlanto 2001). The most important uses of camel's milk are as drug against autoimmune diseases, dropsy, jaundice, splenomegaly, asthma, anemia, piles and diabetes with antimicrobial and antitoxic effects (Soliman et al 2015). The improvement in immune function using dietary antioxidants as camel whey can play an important role in the prevention of many human diseases and diabetic complications. Dietary whey supplementations may improve wound healing by increasing GSH synthesis and cellular antioxidant defense (Velioglu Ogünç et al 2008). As known, camel milk contains insulin-like peptides and other substances that modulate glucose level (Mohamad et al 2009; Zagòrski et al 1998; Agrawal et al 2003).

There is a growing worldwide trend that camel milk consumption helps in prevention and control of diabetes (Malik et al 2012). The presence of peptides in camel's milk exhibits its biological activities that have a valuable effect on digestion, absorption, growth and immunity (Korhonen and Pihlanto 2001) and antitoxic effect against some heavy metals and drugs (Al-Hashem 2009; Afifi 2010; Khan and Alzohairy 2011). CM is beneficial in reducing the dose of insulin needed to induce glycemic control and improves fasting blood glucose, glycosylated hemoglobin, serum anti-insulin antibodies, urinary albumin excretion, and mass body index (Agrawal et al 2009; Mohamad et al 2009). Regular consumption of $\mathrm{CM}$ for few months improved the condition of diabetic patients and experimental animal models (Sboui et al 2010; Mohamad et al 2009; Agrawal et al 2005 and 2011). Most published data about the way by which any treatment may affect the response of diabetic patients and experimental animal models is not completely explained (Mima et al 2008; WHO 2011; Hesham et al 2012). Therefore, this study focused on examining the changes in biochemical alterations during diabetes, changes in gene expression of lipids and carbohydrate metabolism and how to prevent or modulate diabetes incidence by camel milk supplementation. Moreover, the histopathological changes using immunohistochemical stains for pancreas was used to clarify the medical importance of CM supplementation in treatment of diabetes.

\section{Materials and Methods Camel's milk preparation}

Camel's milk samples were collected daily in the morning from camel farm in Turabah governorate, Mecca princedom, KSA. Milk was collected from healthy camels (4 years old) by hand milking and kept in sterile screw bottles and kept under cooling conditions until transported to the laboratory. Rats supplemented with unpasteurized camel milk.

\section{Experimental Design}

Seventy-five adult male rats of the albino type, 8 weeks old, 200 gram body weight were purchased from King Fahd center for Scientific Research, King Abdel-Aziz University, Jeddah, KSA. Rats were kept for one week for acclimatization. All animal procedures were approved by the Ethical Committee Office of the dean of scientific affairs of Taif University, Saudi Arabia. Rats were divided into five groups (each group were handled in triplicate; 5 rats per one cage in triplicate; 15 rat per group). Group 1 as used as a control and received free access to food and water. Group 2 supplemented with camel milk (CM). Diabetes was induced in the remaining forty-five rats by intraperitoneal injection of STZ (60 mg/kg bw, Sigma-Aldrich St. Louis, MO, USA) based on protocol stated by Saleh et al (2016). To avoid the sudden death of the diabetic rats due to hypoglycemia, rats were supplemented with $5 \%$ glucose solution for the next $12 \mathrm{~h}$ following STZ injection. Diabetes was confirmed after $72 \mathrm{hrs}$ of STZ injection by measuring blood glucose levels using commercially available glucose detector. Rats with glucose levels over $220 \mathrm{mg} / \mathrm{dL}$ considered diabetic and used for 


\section{Mansour et al., Afr J Tradit Complement Altern Med., (2017) 14 (4): 108-119 \\ https://doi.org/10.21010/ajtcam.v14i4.13}

subsequent groups. The positive diabetic rats divided into groups 3, 4 and 5. Group 3 served as positive diabetic control (D). Group 4 diabetic and administered metformin (D+MET). Group 5 served as diabetes and supplemented with CM (D+CM). CM was given orally to group 2 and 4 at a dose of $250 \mathrm{ml} / 24$ hours/15 rats based on study of Althnaian (Althnaian et al 2013). CM dose can be equated as $83.33 \mathrm{ml} / \mathrm{kg}$ bw daily for 2 consecutive months. The experiment was repeated three times each time with five animals for reproductively. Twenty-four hours after last administrations, all rats were sacrificed after anesthetization by diethyl ether inhalation. Blood, liver, and adipose tissues were collected. Liver and adipose tissues were kept in TRIzol® reagent (Life Technologies, USA) at $-80^{\circ} \mathrm{C}$ in a deep freezer for ribonucleic acid (RNA) extraction and maintained in $10 \%$ neutral buffered formalin (NBF) at room temperature for 24 hours for immunohistochemical study.

\section{Serum biochemical measurements}

Triglycerides (TG), total cholesterol (TC), and high-density lipoproteins (HDL) were measured using commercial spectrophotometric analysis kits (Bio-Diagnostic Company, Giza, Egypt). Insulin and leptin levels were measured using spectrophotometric commercial kits bought from Chrystal Chem Co, Downers Grove, IL 6051 USA. Glucose was measured using commercial glucose monitoring set (ACCU-Chek). Liver, renal biomarkers, antioxidants and MDA were measured spectrophotometrically as indicated in instruction manuals of each kit.

\section{RNA Extraction}

Total RNA was extracted from adipose and liver tissues samples as stated previously (Ahmed and Ahmed 2016). RNA concentration and purity determined by BIO-RAD SmartSpecPlus UV/Visible Spectrophotometer (USA). RNA integrity was examined by running through $1.5 \%$ denaturated agarose gel stained with ethidium bromide.

\section{Semi-quantitative RT-PCR analysis}

Three micrograms of total RNA and $0.5 \mathrm{ng}$ oligo dT primer (Qiagen Valencia, CA, USA) were used for cDNA synthesis. The total volume was adjusted up to $11 \mu \mathrm{l}$ by sterilized DEPC water and incubated in the Bio-Rad T100TM Thermal cycler at $65^{\circ} \mathrm{C}$ for $10 \mathrm{~min}$ for denaturation. Then, $2 \mu \mathrm{l}$ of $10 \mathrm{X}$ RT-buffer, $2 \mu 1$ of $10 \mathrm{mM} \mathrm{dNTPs}$ and $100 \mathrm{U}$ Moloney Murine Leukemia Virus (M-MuLV) Reverse Transcriptase (Sib Enzyme. Ak, Novosibirsk, Russia) were added. The total volume was adjusted up to $20 \mu \mathrm{l}$ by adding DEPC water. The mixture was then kept in BIO-RAD thermal cycler at $37^{\circ} \mathrm{C}$ for one hour, re-heated for $10 \mathrm{~min}$ at $90^{\circ} \mathrm{C}$ for enzyme deactivation. Specific primers for examined genes (Table 1 ) were designed using Primer3Plus online software (http://primer3plus.com/) and synthesized by Macrogen (Macrogen Company, Korea). $1 \mu \mathrm{l}$ cDNA was mixed with $1 \mu \mathrm{l}$ of $10 \mathrm{pm}$ of each primer, and $12.5 \mu 1$ PCR master mix (Promega USA).

The final volume was brought up to $25 \mathrm{ml}$ using sterilized, deionized water. PCR was carried out using Bio-Rad T100TM Thermal Cycler with a cycle sequence at $94^{\circ} \mathrm{C}$ for 5 minutes one cycle, followed by 31 cycles (Table 1 ) each of which consists of denaturation at $94{ }^{\circ} \mathrm{C}$ for one minute, annealing at the specific temperature corresponding to each primer (Table 1) and extension at $72{ }^{\circ} \mathrm{C}$ for one minute with an additional final extension at $72{ }^{\circ} \mathrm{C}$ for 7 minutes. Glyceraldehyde3 -phosphate dehydrogenase (GAPDH) mRNA was used as a reference. The PCR products were electrophoresed on $1.5 \%$ agarose gel, stained with $0.1 \mu \mathrm{g} / \mathrm{ml}$ of ethidium bromide. PCR products were photographed and subjected to band intensity analysis using Image J software v. 1.47 (http://imagej.en.softonic.com/).

Table (1): PCR conditions and primers sequence of examined genes.

\begin{tabular}{|c|c|c|c|c|}
\hline Gene & Primer sequence (5'-3') & & Annealing Temp. & Band size \\
\hline \multirow{2}{*}{ GAPDH } & AGATCCACAACGGATACATT & (F) & \multirow{2}{*}{52} & \multirow{2}{*}{309 bp } \\
\hline & TCCCTCAAGATTGTCAGCAA & (R) & & \\
\hline \multirow{2}{*}{$P K$} & ATTGCTGTGACTGGATCTGC & (F) & \multirow{2}{*}{52} & \multirow{2}{*}{229 bp } \\
\hline & CCCGCATGATGTTGGTATAG & (R) & & \\
\hline \multirow{2}{*}{ PEPCK } & TTTACTGGGAAGGCATCGAT & (F) & \multirow{2}{*}{52} & \multirow{2}{*}{$236 \mathrm{bp}$} \\
\hline & TCGTAGACAAGGGGGCAC & (R) & & \\
\hline \multirow{2}{*}{$I R S-2$} & CTACCCACTGAGCCCAAGAG & (F) & \multirow{2}{*}{55} & \multirow{2}{*}{$151 \mathrm{bp}$} \\
\hline & CCAGGGATGAAGCAGGACTA & (R) & & \\
\hline \multirow{2}{*}{ FASN } & CCAGAGCCCAGACAGAGAAG & (F) & \multirow{2}{*}{61} & \multirow{2}{*}{$345 b p$} \\
\hline & GACGCCAGTGTTCGTTCC & (R) & & \\
\hline \multirow{2}{*}{$C P T-1$} & TATGTGAGGATGCTGCTTCC & $(\mathrm{F})$ & \multirow{2}{*}{52} & \multirow{2}{*}{$628 \mathrm{bp}$} \\
\hline & CTCGGAGAGCTAAGCTTGTC & (R) & & \\
\hline
\end{tabular}




\section{Mansour et al., Afr J Tradit Complement Altern Med., (2017) 14 (4): 108-119 \\ https://doi.org/10.21010/ajtcam.v14i4.13}

\section{Immunohistochemical analysis of pancreatic insulin}

Rat Pancreas was fixed in 10\% buffered neutral formalin then washed, dehydrated in ascending grades of ethyl alcohol then cleared in xylene, embedded in paraffin, sectioned at 5 micron thickness, deparaffinized, and then treated with $3 \% \mathrm{H} 2 \mathrm{O} 2$ for $10 \mathrm{~min}$ to block the peroxidases activity. Subsequently, the tissue samples were heated at $121^{\circ} \mathrm{C}$ in $10 \mathrm{mM}$ citrate buffer for $30 \mathrm{~min}$, blocked for $20 \mathrm{~min}$ in 5\% normal serum. The pancreatic tissue was incubated overnight with rabbit polyclonal anti-insulin primary antibody (1:100; sc-9168; Santa Cruz Biotechnology, Inc., Dallas, TX, USA) or with GLUT4 Antibody (1:100; sc-53566; Santa Cruz Biotechnology, Inc., Dallas, TX, USA) in phosphate-buffered saline (PBS) at $4^{\circ} \mathrm{C}$. After three extensive washes with PBS, the sections were incubated with a goat anti-rabbit IgG biotin conjugated secondary antibody (1:2,000; sc-2040; Santa Cruz Biotechnology, Inc.) for $20 \mathrm{~min}$ at $32^{\circ} \mathrm{C}$. After further incubation with horseradish peroxidase-labeled streptavidin, antibody binding was visualized using diaminobenzidine, and the sections were counterstained with hematoxylin.

\section{Statistical analysis}

Data are presented as means \pm standard error of means (SEM) for 3 independent experiments per each treatment. Results were analyzed using analysis of variance (ANOVA) and post hoc descriptive tests by SPSS software v 11.5 (SPSS, IBM, Chicago, IL, USA) with $p<0.05$ regarded as statistically significant.

\section{Results}

\section{Analysis of serum chemistry in diabetic rats:}

Effect of camel milk supplementation on glucose, insulin and leptin levels in diabetic rats

Diabetic rats supplemented with camel milk showed a decrease in glucose levels compared to diabetic rats (D). This is coincided with the decrease reported in metformin administered diabetic rats (D+MET) as a positive therapeutic group. The changes in glucose levels are mainly due to the increase in insulin secretion reported in camel milk administered diabetic rats $(D+C M)$ as seen in the Table (2). Leptin levels were decreased in diabetic group and was increased in metformin diabetic rats (D + MET) while CM administration normalized and increased it in a way to increase peripheral glucose utilization and homeostasis $(\mathrm{D}+\mathrm{CM})$ as seen in table 2.

Table (2): serum changes in glucose levels, insulin and leptin in diabetic rats and after camel milk administration for 2 months

\begin{tabular}{cccc}
\hline Group & $\begin{array}{c}\text { Glucose } \\
(\mathrm{mg} / \mathrm{dL})\end{array}$ & $\begin{array}{c}\text { Insulin } \\
(\mu \mathrm{U} / \mathrm{ml})\end{array}$ & $\begin{array}{c}\text { Leptin } \\
(\mathrm{ng} / \mathrm{ml})\end{array}$ \\
\hline Control (C) & $83.0 \pm 9.7$ & $35.3 \pm 2.3$ & $12.6 \pm 3.1$ \\
Diabetes (D) & $462.3 \pm 37.8^{*}$ & $8.3 \pm 0.5^{*}$ & $9.1 \pm 5.1^{*}$ \\
Diabetes + metformin (D+MET) & $120.0 \pm 10.1 \#$ & $27.2 \pm 3.4 \#$ & $17.2 \pm 5.3 \#$ \\
Control + Camel milk (CM) & $85.7 \pm 5.8$ & $39.3 \pm 6.3$ & $10.0 \pm 1.6$ \\
Diabetes + Camel milk (D+CM) & $96.7 \pm 11.1 \#$ & $33 \pm 2.3 \#$ & $10.4 \pm 1.3 \#$ \\
\hline
\end{tabular}

Values are means \pm standard error (SEM) for 3 independent experiments per each treatment. Values are statistically significant at $* p<0.05$ Vs. control; \#p<0.05 Vs. diabetic group \#p<0.05 Vs. diabetic metformin group.

\section{Effect of camel milk supplementation on kidney and liver biomarkers in diabetic rats}

Due to oxidative stress induced by diabetes, diabetic rats showed significant an increase in serum levels of urea, creatinine, GPT and GOT (Table 3). Administration of camel milk to diabetic rats (D+CM) normalized these changes. The results reported for camel milk in diabetic rats are the same reported for control positive metformin administered rats (D+MET). 


\section{Mansour et al., Afr J Tradit Complement Altern Med., (2017) 14 (4): 108-119 \\ https://doi.org/10.21010/ajtcam.v14i4.13}

Table (3): Serum changes in kidney and liver function parameters in diabetic rats and after camel milk administration for 2 months.

\begin{tabular}{ccccc}
\hline Group & Urea $(\mathrm{mg} / \mathrm{dL})$ & Creatinine $(\mathrm{mg} / \mathrm{dL})$ & $\begin{array}{c}\text { GPT } \\
(\mathrm{U} / \mathrm{L})\end{array}$ & $\begin{array}{c}\text { GOT } \\
(\mathrm{U} / \mathrm{L})\end{array}$ \\
\hline Control (C) & $43.0 \pm 9.2$ & $0.8 \pm 0.1$ & $103.6 \pm 7.7$ & $90.6 \pm 7.6$ \\
Diabetes (D) & $111.7 \pm 14.8^{*}$ & $2.4 \pm 0.2^{*}$ & $169.1 \pm 15.1^{*}$ & $181.1 \pm 5.1^{*}$ \\
Diabetes + metformin & $69.0 \pm 22.4 \#$ & $1.1 \pm 0.3 \#$ & $99.2 \pm 25.3 \#$ & $121.7 \pm 14.9 \#$ \\
$(\mathrm{D}+\mathrm{ME})$ & $40.7 \pm 5.8$ & $0.9 \pm 0.2$ & $86.0 \pm 2.5$ & $96.0 \pm 16.3$ \\
$\begin{array}{c}\text { Control + Camel milk } \\
(\mathrm{C}+\mathrm{CM})\end{array}$ & $66.2 \pm 8.5 \#$ & $0.7 \pm 0.02 \#$ & $103.7 \pm 24.2 \#$ & $70.7 \pm 13.0 \#$ \\
$\begin{array}{c}\text { Diabetes + Camel milk } \\
(\mathrm{D}+\mathrm{CM})\end{array}$ & & & & \\
\hline
\end{tabular}

Values are means \pm standard error (SEM) for 3 independent experiments per each treatment. Values are statistically significant at $* p<0.05 \mathrm{Vs}$. control; \#p<0.05 Vs. diabetic group \#p<0.05 Vs. diabetic metformin group. GPT; glutamate pyruvate transaminase; GOT; Glutamic-oxaloacetate transaminases.

\section{Effect of camel milk supplementation on oxidative stress and antioxidants levels of diabetic rats}

The changes in malondialdehyde (MDA) levels are seen in table 4. Diabetic rats showed an increase in MDA levels and CM administration normalized MDA levels in CM administered diabetic rats (Table 4). Catalase (CAT), glutathione reductase (GR), and superoxide dismutase (SOD) were decreased in diabetic rats. The percent decrease in antioxidant enzymes were about $71 \%$ compared to control group (C). Antioxidants levels were normalized in diabetic rats after CM supplementation (D+CM; table 4).

Table (4): Serum changes in MDA and antioxidants levels in diabetic rats and after camel milk administration for 2 months.

\begin{tabular}{ccccc}
\hline Group & $\begin{array}{c}\text { MDA } \\
\text { (nmol/g tissue) }\end{array}$ & $\begin{array}{c}\text { CAT } \\
\text { (U/g tissue) }\end{array}$ & $\begin{array}{c}\text { GR } \\
\text { (U/g tissue) }\end{array}$ & $\begin{array}{c}\text { SOD } \\
\text { (U/g tissue) }\end{array}$ \\
\hline Control (C) & $4.5 \pm 0.1$ & $31.4 \pm 2.0$ & $9.4 \pm 0.4$ & $11.5 \pm 0.3$ \\
Diabetes (D) & $28.5 \pm 1.8^{*}$ & $8.7 \pm 0.5^{*}$ & $3.1 \pm 0.1^{*}$ & $2.9 \pm 0.2^{*}$ \\
Diabetes + metformin (D+ME) & $14.1 \pm 3.8 \#$ & $26.4 \pm 2.4 \#$ & $7.5 \pm 1.0 \#$ & $9.8 \pm 1.2 \#$ \\
Control + Camel milk (C+CM) & $11.6 \pm 4.0$ & $31.4 \pm 6.1$ & $9.4 \pm 0.4$ & $10.7 \pm 1.0$ \\
Diabetes + Camel milk (D+CM) & $8.3 \pm 0.3$ & $32.3 \pm 1.8 \#$ & $9.8 \pm 0.3 \#$ & $11.4 \pm 0.5 \#$ \\
\hline
\end{tabular}

Values are means \pm standard error (SEM) for 3 independent experiments per each treatment. Values are statistically significant at $* p<0.05 \mathrm{Vs}$. control; \#p<0.05 Vs. diabetic group \#p<0.05 Vs. diabetic metformin group. (GR); Glutathione reductase, (MDA); malondialdehyde, (CAT); Catalase, (SOD); super oxide dismutase.

Effect of camel milk supplementation on total cholesterol, triglycerides and high density lipoproteins in diabetic rats

A significant increase in the total cholesterol (TC), triglycerides (TG) and a decrease in high-density lipoproteins (HDL) levels were reported in diabetic rats. Camel milk administration ameliorated and normalized the increase in TC and TG levels in diabetic rats (D+CM). In parallel, CM supplementation increased HDL levels compared to diabetic group alone. The ameliorated effect induced by camel milk is relatively the same reported for metformin administered rats (D+MET) as seen in table 5.

Table (5): Serum changes in lipid parameters in diabetic rats and after camel milk administration for 2 months

\begin{tabular}{cccc}
\hline Group & TC (mg/dL) & TG (mg/dL) & HDL(mg/dL) \\
\hline Control (C) & $93.7 \pm 10.2$ & $53.3 \pm 2.8$ & $19.7 \pm 0.9$ \\
Diabetes (D) & $252.7 \pm 18.2^{*}$ & $128.3 \pm 11.8^{*}$ & $8.9 \pm 4.1^{*}$ \\
Diabetes + metformin (D+ME) & $161.2 \pm 21.8 \#$ & $85.7 \pm 9.1 \#$ & $16.2 \pm 0.6 \#$ \\
Control + Camel milk (C+CM) & $104.7 \pm 19.2$ & $77.7 \pm 9.8$ & $20.3 \pm 0.9$ \\
Diabetes + Camel milk (D+CM) & $100.0 \pm 6.6 \#$ & $72.3 \pm 0.5 \#$ & $15.7 \pm 2.2 \#$ \\
\hline
\end{tabular}

Values are means \pm standard error (SEM) for 3 independent experiments per each treatment. Values are statistically significant at $*_{p}<0.05 \mathrm{Vs}$. control; \#p<0.05 Vs. diabetic group \#p<0.05 Vs. diabetic metformin group. (TC) total cholesterol, (TG) triglycerides, (HDL) high density lipoprotein. 
Mansour et al., Afr J Tradit Complement Altern Med., (2017) 14 (4): 108-119

https://doi.org/10.21010/ajtcam.v14i4.13

Effect of camel milk supplementation on hepatic gene expression of carbohydrates and lipids metabolism in diabetic rats

The effect of camel milk on the expression of some genes related to carbohydrate and lipid metabolism altered during diabetes are shown in Figs (1 and 2). As shown in figure 1, CM administration alone did not affect the expression of PEPCK gene in diabetic group (D+CM). The mRNA expression of IRS-2 gene was down-regulated in diabetic rats (D) and increased in positive metformin diabetic rats (D+MET). CM administration increased significantly mRNA expression of $I R S-2$ in $\mathrm{CM}$ administered diabetic rats $(\mathrm{D}+\mathrm{CM})$ in parallel with results reported for metformin diabetic group. A similar change in mRNA expression of $P K$ occurred and was the same like in IRS-2 gene. On the other hand, figure 2 shows that the expression of $C P T-1$ was increased due to diabetic rats (D). Metformin administration failed to inhibit the up-regulation occurred in diabetic rats. Interestingly, CM administration restored the expression level of CPT-1 to normal levels as compared to control group (C). Moreover, CM supplementation up-regulated the transcription of FASN mRNA in diabetic rats $(\mathrm{D}+\mathrm{CM})$ in same pattern reported for metformin diabetic rats (Figure 2). 
Mansour et al., Afr J Tradit Complement Altern Med., (2017) 14 (4): 108-119

https://doi.org/10.21010/ajtcam.v14i4.13
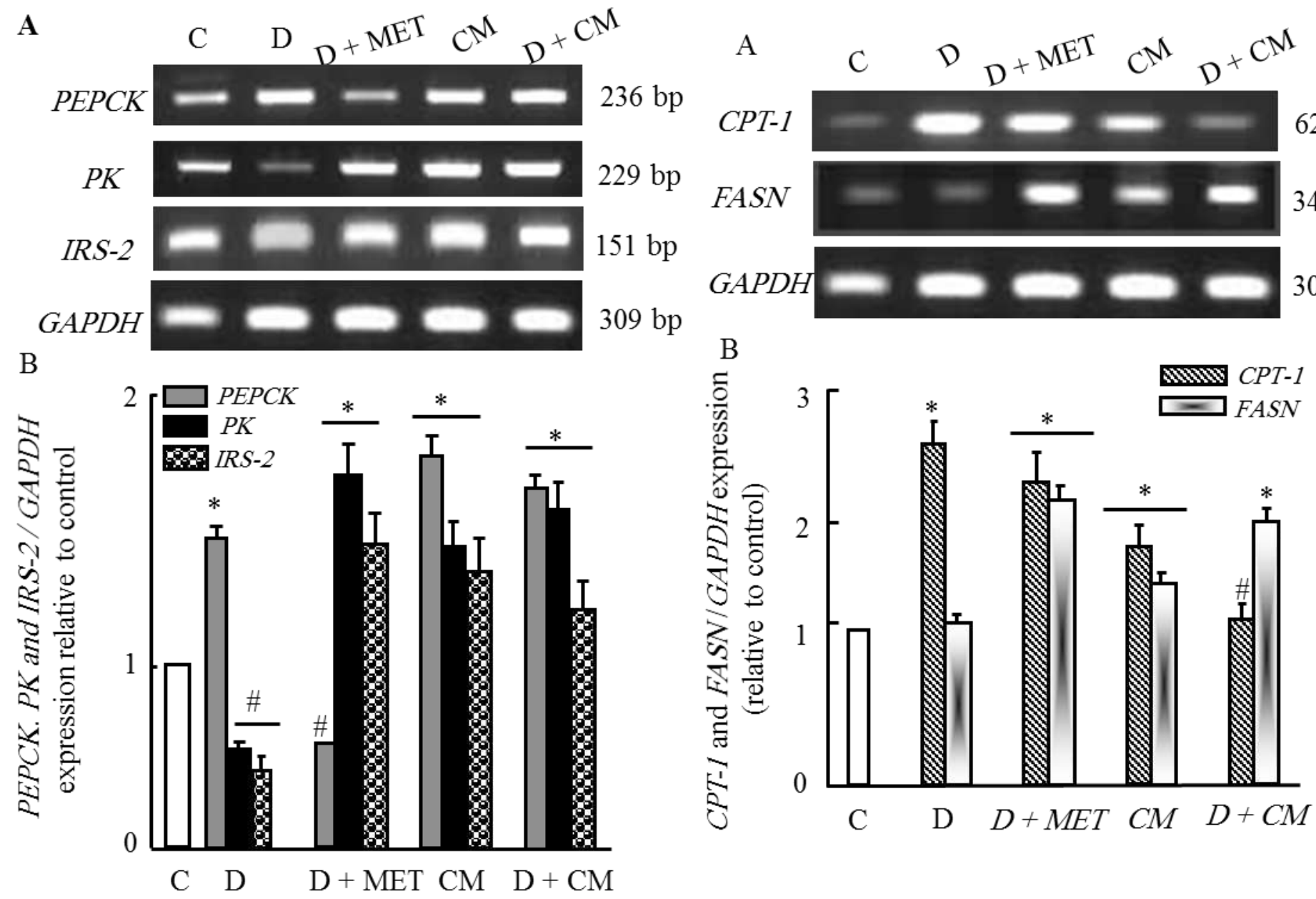

$628 \mathrm{bp}$

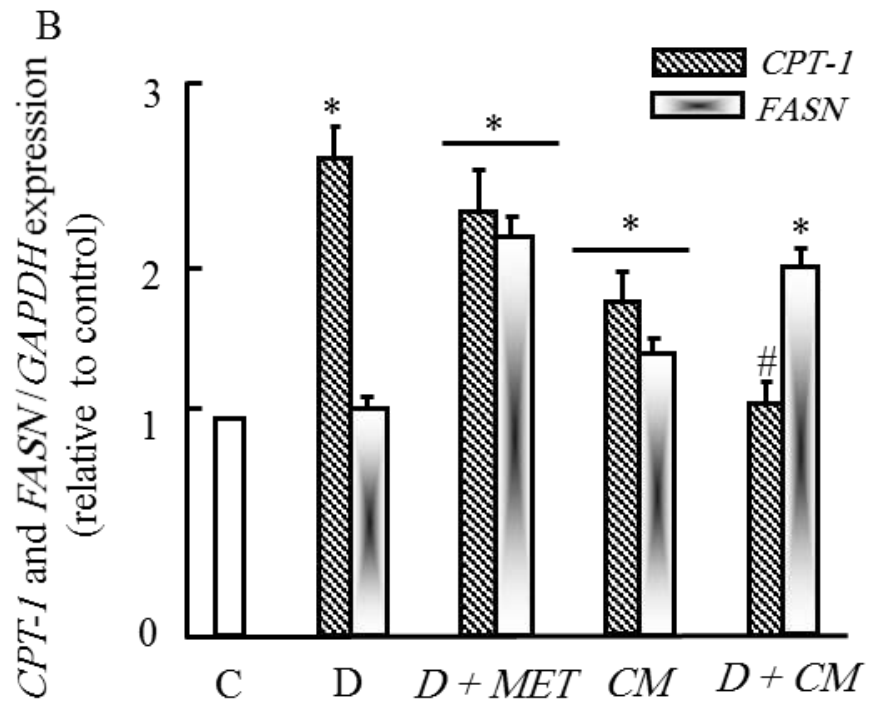

Figure 1: Semi-quantitative RT-PCR analysis of PEPCK, $P K$ and IRS-2 mRNA expressions and their corresponding $G A P D H$ in the rat liver tissue. RNA was extracted and reverse-transcribed $(3 \mu \mathrm{g})$, and RT-PCR analysis was carried out for examined genes as described in the Materials and methods. Densitometric analysis was carried for 15 different rats per each group. Values are means \pm SEM obtained from 5 rats in triplicate per group. $* P<0.05$ vs. control group, and $\# P<0.05$ vs. diabetic group.

Immunohistochemical analysis of pancreatic insulin after camel milk supplementation in diabetic rats

The pancreas of control rats showed normal tissue architecture with regular insulin expression in the pancreatic $\beta$ cells (Fig. 3A). CM and metformin administered control rats (C+CM) and (C+MET) showed normal insulin expression in pancreatic beta cells (Figs. 3B \& 3C respectively). The pancreatic tissue from diabetic rats (D) exhibited a reduction in the expression of insulin, with atrophy of the pancreatic $\beta$-cells (Fig. 3 D). Finally, the pancreas of CM administered diabetic rats $(\mathrm{D}+\mathrm{CM})$ exhibited regenerative restoration of normal expression of insulin in the pancreatic $\beta$-cells (Fig. $3 \mathrm{E}$ ). On the same line, pancreas of control rats (C) presented normal GLUT4 expression in the pancreatic tissues (Fig. 3F). CM and metformin aministered control rats $(\mathrm{C}+\mathrm{CM})$ and $(\mathrm{C}+\mathrm{MET})$ showed normal GLUT-4 expression in pancreatic tissue (Figs. $3 \mathrm{G} \& 3 \mathrm{H}$ respectively). However, the pancreatic tissue from diabetic rats (D) exhibited a reduction in the expression of 114 


\section{Mansour et al., Afr J Tradit Complement Altern Med., (2017) 14 (4): 108-119 \\ https://doi.org/10.21010/ajtcam.v14i4.13}

GLUT4 (Fig. 3I) while the pancreas of the group (D+CM) exhibited restoration of normal expression of GLUT4 in the pancreatic tissue (Fig. 3J).

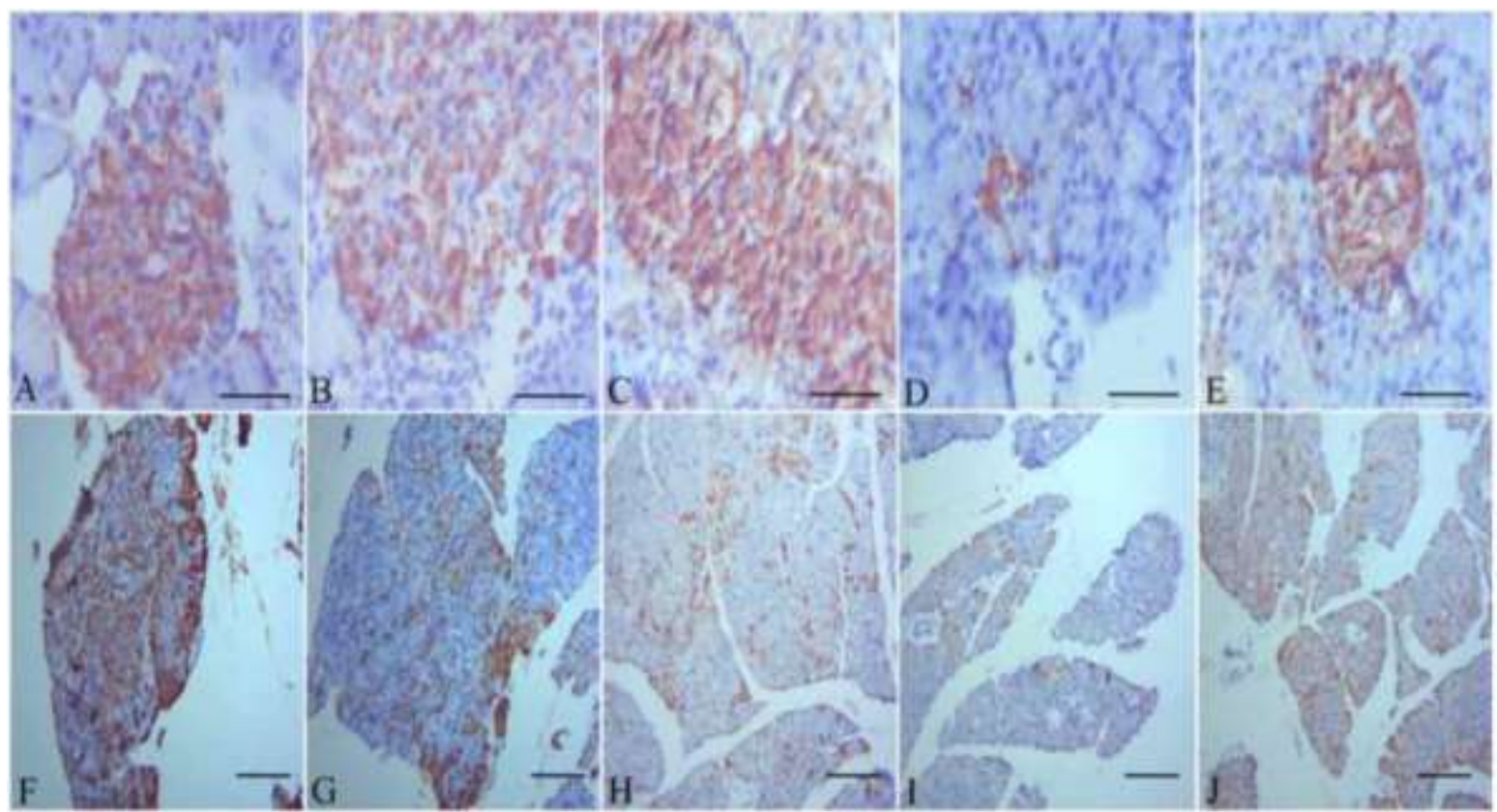

Figure 3: (A): Pancreatic tissue of a healthy control rat showing a normal architecture with normal expression of insulin in the $\beta$ cells (magnification, x1200). (B): Pancreatic tissue of camel milk administered rat showing normal expression of insulin in the $\beta$ cells. (C): Pancreatic tissue of metformin administered rat showing normal insulin expression in the $\beta$ cells. (D): Pancreatic tissue of streptozotocin administered rat showing a reduction in the expression of insulin in the $\beta$ cells, with atrophy of the $\beta$ cells (magnification, x1200). (E): Pancreatic tissue of Streptozotocin administered rat treated with camel milk showing the restoration of normal expression of insulin in the pancreatic $\beta$ cells (magnification, $\mathrm{x} 1200$ ). (F): the pancreas of the healthy control rats presented normal GLUT-4 expression in the pancreatic tissue (magnification, $\mathrm{x} 150$ ). (G): The pancreas of camel milk administered rats showed normal expression of GLUT-4 in the pancreatic tissue (magnification, x150). (H): The pancreas of metformin administered rats presented normal GLUT-4 expression. (I): the pancreatic tissue from the diabetic rats exhibited a reduction in the expression of GLUT-4 (magnification, x150). (J): the pancreas of the diabetic treated with camel milk exhibited restoration of normal expression of GLUT-4 in the pancreatic tissue (magnification, $\mathrm{x} 150$ ). Scale bar for photos from A to $\mathrm{E}$ is $50 \mu \mathrm{m} \&$ for photos from $\mathrm{F}$ to $\mathrm{J}$ is $100 \mu \mathrm{m}$.

\section{Discussion}

Traditional medicine is a common way used in public remedy; the desert Bedouins use different varieties of natural materials including animal products in treating diseases. A large number of articles mentioned the benefits of camel milk (Malik et al 2012; Hanieh et al 2015; Laila et al 2015). Our results showed that administration of camel milk reduced the levels of serum glucose and restored the average level of leptin in the treated diabetic rats because camel milk contains insulin nanoparticles which are protected from digestive tract proteases and absorbed directly in the intestine (Malik et al 2012; Al-Hashem 2009; Kamal et al 2007; Abd El-Aziz et al 2012). As known, the insulin contained in camel milk has same features as human insulin (Malik et al 2012). Moreover, the camel milk keeps its liquidity form in the environment of the low stomach pH. Camel milk has an advantage, that it contains 'insulin-like' small molecule substances that mimic insulin interaction with its receptor, for that, it can be suitable for treating the patients who have insulin resistance (T2D) (Malik et al 2012). Diabetes has a strong relationship with renal and liver diseases (Mazen and John 2015). Camel milk protected the liver and kidney function from failure; we suppose that camel milk contains insulin nanoparticles that safeguard the role of kidney and liver by restoring the normal glucose levels in the blood. Previous studies (Sharma et al 2012; Saleh et al 2016; Merecz et al 2015), reported that diabetes increases the induction of oxidative stress by elevating the level of MDA and decreasing antioxidant concentrations in the serum, and that coincides with our results. Zeineb et al 


\section{Mansour et al., Afr J Tradit Complement Altern Med., (2017) 14 (4): 108-119 \\ https://doi.org/10.21010/ajtcam.v14i4.13}

2014, investigated the antioxidant activity of camel milk and found that the casein of camel milk inactivates the reactive oxygen species by scavenging the free radicals. Mohamad et al (2009) and Hanieh et al (2015) evaluated the effects of camel milk on the TC, HDL and TG levels in T1D and T2D respectively, their findings agreed with our results that, CM normalized the alteration in HDL and TG, while reduced the increase in TC levels. Therefore, camel milk can give promising results when used as dietary supplement for patients of T1D. Insulin plays a main role in the regulation of PEPCK, IRS-2, CPT-1, PK and FASN gene expression (Quinn and Yeagley 2005; O'Brien et al 1990). PEPCK enzyme catalyzes the rate-controlling step of gluconeogenesis. Insulin is a dominant negative regulator of $P E P C K$ gene transcription (Kaushik and Richard 2007). Our results showed that camel milk did not reduce the expression of $P E P C K$ gene. Probably the increase in both insulin and leptin levels are the cause for this effect. As both hormones can regulate glucose levels, therefore, no need for the gluconeogenesis. Insulin resistance is the leading cause of T2D, which is correlated with reduction in expression of both major insulin receptor substrate (IRS) proteins, (IRS-1) and (IRS-2) (Fisher and Kahn 2003). Our results showed that camel milk provoked the activity of ISR-2 while metformin failed to achieve this goal. Metformin works directly on the reduction of glucose production from non-carbohydrate carbon substrates in the liver through gluconeogenesis metabolic pathway (Michael and Deborah 2001). The reduction of IRS-2 expression causes severe reduction of $\beta$-cells (Kubota et al 2000). Camel milk contains zinc, which has a key role in the insulin maturation and secretion in pancreatic $\beta$-cells (Gisela 2005), in addition to the presence of camel milk immunoglobulin may offer massive potentials by interaction with the host cell protein that cause an enhancement of regulatory cells and leads to downregulation of the immune system and salvage the $\beta$-cells (Agrawal et al 2007). Various published data reported that insulin stimulates expression of the $P K$ gene which is responsible for the increase in hepatic glycolysis to help in peripheral glucose utilization (Yuuki et al 2003; Yamada and Tanaka 1999). Administration of camel milk normalized the expression of CPT-1 level in the diabetic rats, reduced the TG levels to normal levels and elevated the levels of high-density lipoprotein cholesterol (HDL). There is an inverse relationship between $C P T-1$ expression and triglycerides content in the cell. Insulin reduces the expression of $C P T-1$ and increases glycogen and triacylglycerides synthesis. Furthermore administration of camel milk inhibited lipolysis associated with diabetes because the used camel milk is already nondefatted. The FASN gene is the enzyme involved in converting acetyl-CoA into fatty acids (lipogenesis). Insulin plays a key role in the regulation of fatty acid synthase (FAS). It does increase the rate of FASN gene transcription and FAS enzymatic activity. Conversely, in the case of insulin resistance FASN is markedly inactivated (Jose et al 2010). The results showed that administration of camel milk enhanced the expression of FASN gene. This enhancement is referred to the insulin particles included in the camel milk. We boosted our investigation by the immunohistochemical test. STZ induced diabetes by destroying the pancreatic $\beta$-cells (Eleazu et al 2013; Sharma et al 2012). Checking the amount of produced insulin is a good indicator of the normal case of Langerhans islets $\beta$-cells because the active insulin is secreted from secretory granules in the $\beta$-cells (Agrawal et al 2007).

Our results showed that administration of camel milk showed restoration of insulin secretion in diabetic rats; this means that the Langerhans islets $\beta$-cells restored their activity. There are three possibilities to explain this result; (1) regeneration has occurred of distorted $\beta$-cells, this explanation agrees with Srinivasan and Ramarao (2007) who mentioned that there is a spontaneous regeneration of damaged $\beta$-cells in the chemically induced diabetes. (2) The undamaged $\beta$-cells secretes insulin with overdose to compensate the shortage caused by damaged cells, (3) camel milk reduced the STZ damage effects occurred in the $\beta$-cells; this explanation congruent with Hamers et al. (1993). Furthermore, camel milk has antitoxic effects against drugs (Afifi 2010; Khan and Alzohairy 2011; Al-Fartosi et al 2011), as well as antioxidant effects (Zeineb et al 2014) that reduced the STZ dangerous effects. GLUT-4 is insulin-responsive glucose transporter, which diffuses glucose into adipose and muscular tissues (Stenbit et al 1997). We indicated that; the reduction of GLUT-4 appeared in the diabetic rats (under immunohistochemical examination) reflects the decrease in insulin secretion. Because the expression of GLUT-4 is stimulated by cascade gene regulation enhanced by secretion of insulin hormone (Gisela 2005). Administration of camel milk restored the expression of GLUT-4 in the pancreas tissue which is detected by the immunohistochemical staining, camel milk already contains insulin as mentioned in different articles (Malik et al 2012; AlHashem 2009; Kamal et al 2007; Abd El-Aziz et al 2012) as well as it restored the activity of the $\beta$-cells as we mentioned previously.

\section{Conclusion}

Camel milk is a natural product that can be considered as a nutritional supplement that helps in treatment of diabetes and it metabolic associated disorders such as insulin resistance. It has dynamic effects on the regulation of CPT-I, FASN, PK and IRS-2 expression, stimulation of insulin production and secretion from the pancreas. CM ameliorated and normalized the changes in glucose, TC, TG, and HDL levels in the blood of diabetic rats. 


\section{Mansour et al., Afr J Tradit Complement Altern Med., (2017) 14 (4): 108-119 \\ https://doi.org/10.21010/ajtcam.v14i4.13}

\section{Ethics approval and consent to participate}

All procedures used in treating animals were approved by the Ethical Committee Office of the dean of scientific affairs of Taif University, KSA.

\section{Author Contributions}

All authors participated in acquisition, analysis or interpretation of the data, in the drafting of the article or critical revision and in final approval of the version to be published; all authors agreed to be accountable for all aspects of the work in ensuring that questions related to the accuracy or integrity of any part of the article are appropriately investigated and resolved.

\section{References}

1. Abd El-Aziz, A.D., Ali, K.A., Ahmed, A.H., Mansour, H.Z and Mohamed, M.S. (2012). A study on the effect of female camel (Camelus dromedarius) milk on glycemic control of streptozotocin (STZ) induced diabetes mellitus in rats. $\mathrm{J}$ American Science 8: 459-465.

2. Al-Baghli NA, Al-Ghamdi AJ., Al-Turki KA, Al Elq AH, El-Zubaier AG and Bahnassy A. (2011). Prevalence of diabetes mellitus and impaired fasting glucose levels in the Eastern Province of Saudi Arabia: results of a screening campaign. Singapore Med. J., 51: 923-930.

3. Afifi, M.E.M. (2010). Effect of camel's milk on cisplatin-induced nephrotoxicity in swiss albino mice. Am J Biochem Biotechnol 6: 141-147.

4. Agrawal, R.P., Beniwal, R., Kochar, D.K., Tuteja, F.C., Ghorui, S.K., Sahani, M.S and Sharma, S. (2005). Camel milk as an adjunct to insulin therapy improves long-term glycemic control and reduction in doses of insulin in patients with type-1 diabetes A 1 year randomized controlled trial. Diabetes Res Clin Pract 68: 176-7.

5. Agrawal, R.P., Dogra, R., Mohta, N., Tiwari, R., Singhal, S and Sultania, S. (2009). Beneficial effect of camel milk in diabetic nephropathy. Acta Biomed 80: 131-134.

6. Agrawal, R.P., Jain, S., Shah, S., Chopra, A and Agarwal, V. (2011). Effect of camel milk on glycemic control and insulin requirement in patients with type I diabetes: 2-years randomized controlled trial. Eur J Clin Nutr 65: 1048-1052.

7. Agrawal, R.P., Saran, S., Sharma, P., Gupta, R., Kochar, D.K and Sahani, M.S. (2007). Effect of camel milk on residual beta-cell function in recent onset type 1 diabetes. Diabetes Res Clin Pract 77: 494e5.

8. Agrawal, R.P., Swami, S.C., Beniwal, R., Kochar, D.K., Sahani, M.S., Tuteja, F.C and Ghouri, S.K. (2003). Effect of camel milk on glycemic control, lipid profile and diabetes quality of life in type 1 diabetes: a randomised prospective controlled cross over study. Indian J Animal Sci 73:1105e10.

9. Ahmed, A.B and Ahmed, A.M. (2016). Genetic and histopathological responses to cadmium toxicity in rabbit's kidney and liver: protection by ginger (Zingiber officinale). Biol Trace Elem Res 170: 320-329.

10. Akbarzadeh, A., Norouzian, D., Mehrabi, M.R., Jamshidi, Sh., Farhangi, A., Verdi, A., Mofidian, S.M.A and Lame Rad, B. (2007). Induction of diabetes by streptozotocin in rats. Indian J of Clinical Biochemistry 22: 60-64.

11. Al-Fartosi, K.G., Khuon, O.S and Al-Tae, H.I. (2011). Protective role of camel's milk against paracetamol induced hepatotoxicity in male rats. Int J Res Pharmaceut Biomed Sci 2: 1795-1799.

12. Al-Hashem, F. (2009). Camel milk protects against aluminum chloride-induced toxicity in the liver and kidney of white albino rats. Am J Biochem Biotechnol 5: 98-108.

13. Althnaian, T., Albokhadaim, I and El-Bahr, S.M. (2013). Biochemical and histopathological study in rats intoxicated with carbon tetrachloride and treated with camel milk. Springer plus 2: 57.

14. Arulmozhi, D.K., Veeranjaneyulu, A and Bodhankar, S.L. (2004). Neonatal streptozotocin-induced rat model of Type 2 diabetes mellitus: A glance. Indian J Pharmacol 36: 217-221.

15. Badr G, Mohany M and Metwalli, A. (2011). Effects of undenatured whey protein supplementation on CXCL12- and CCL21-mediated B and T cell chemotaxis in diabetic mice. Lipids Health Dis. 9; 10:203.

16. Badr, G. (2012). Supplementation with undenatured whey protein during diabetes mellitus improves the healing and closure of diabetic wounds through the rescue of functional long-lived wound macrophages. Cell Physiol Biochem. 29(3-4):57182 . 


\section{Mansour et al., Afr J Tradit Complement Altern Med., (2017) 14 (4): 108-119 \\ https://doi.org/10.21010/ajtcam.v14i4.13}

17. Badr, G. (2013). Camel whey protein enhances diabetic wound healing in a streptozotocin-induced diabetic mouse model: the critical role of $\beta$-Defensin-1, -2 and -3. Lipids Health Dis. 12:46.

18. Badr, G., Ebaid, H., Mohany, M and Abuelsaad, A.S. (2012). Modulation of immune cell proliferation and chemotaxis towards CC chemokine ligand (CCL)-21 and CXC chemokine ligand (CXCL)-12 in undenatured whey protein-treated mice. J Nutr Biochem. 23(12):1640-6.

19. Borchers AT, Uibo R, Gershwin ME. (2010). The geoepidemiology of type 1 diabetes. Autoimmun Rev. 9(5):A355-A365.

20. Eleazu, C.O., Eleazu, K.C., Chukwuma, S and Essien, U.N. (2013). Review of the mechanism of cell death resulting from streptozotocin challenge in experimental animals, its practical use and potential risk to humans. J Diabetes Metab Disord 12: $12-60$.

21. Fisher, S.J and Kahn, C.R. (2003). Insulin signaling is required for insulin's direct and indirect action on hepatic glucose production. J Clin Invest 111:463-468.

22. Forlenza, G. and Rewers, M. (2011). The epidemic of type 1 diabetes: what is it telling us? Curr Opin Endocrinol Diabetes Obes.18(4):248-251.

23. Gaba, R., Gambhire, D., Uy, N., Gonzalez, E.V., Iyer, D and Hampe, C.S. (2015). Factors associated with early relapse to insulin dependence in unprovoked A- $\beta+$ ketosis-prone diabetes. J Diabetes Complications 29: 918-922.

24. Gisela, W. (2005). Insulin and insulin resistance. Clin Biochem Rev 1: 19-39.

25. Hamers, C., Atarbouch, T., Muyldermans, S., Robinson, G., Hamers, C., Songa, E.B., Bendahman, N and Hamers, R. (1993). Naturally occurring antibodies devoid of light chains. Nature 363: 446e8.

26. Hakonarson, H. and Grant, S.F. (2011). Genome-wide association studies (GWAS): impact on elucidating the aetiology of diabetes. Diabetes Metab Res Rev. 27(7):685-96.

27. Hanieh, S.E., Amir, N.N., Parvin, M., Maryam, Z.Y., Mehdi, H., Fereidoun, A and Aliakbar, M.M. (2015). Effect of camel milk on blood sugar and lipid profile of patients with type 2 diabetes: A pilot clinical trial. Int $\mathrm{J}$ Endocrinol Metab 13:e21160.

28. Hesham, M.K., Mohamed, A.M.E., Abdulqader, A.A and Ayman, O.E. (2012). Camel milk modulates the expression of aryl hydrocarbon receptor-regulated genes, Cyp1a1, Nqo1, and Gsta1, in murine hepatomahepa 1c1c7 cells. J Biomed Biotech, 2012 Article ID 782642, 10 pages.

29. Ikebukuro, K., Adachi, Y., Yamada, Y., Fujimoto, S., Seino, Y and Oyaizu, H. (2002). Treatment of Streptozotocininduced diabetes mellitus by transplantation of islet cells plus bone Marrow cells via portal vein in rats. Transplantation 73: 512-518.

30. Jose, M.F.R., Javier, A.M., Jose, M.M.N., Matthias, B., Alejandro, V.M., Maria, J.V., Francisco, O., Carlos, D., Gema, F., Wifredo, R and Antonio, V.P. (2010). Extracellular fatty acid synthase: A possible surrogate biomarker of insulin resistance. Diabetes 59: 1506-1511.

31. Kamal, A.M., Salama, O.A and El-Saied, K.M. (2007). Changes in amino acids profile of camel milk protein during the early lactation. Int J Dairy Sci. 2: 226-234.

32. Kaushik, C and Richard, W.H. (2007). Insulin regulation of phosphoenolpyruvate carboxykinase-c gene transcription: The role of sterol regulatory element- binding protein 1c. Nutrition Reviews 65: S47-S56.

33. Khan, A.A and Alzohairy, M. (2011). Hepatoprotective effects of camel milk against CCl4-induced hepatotoxicity in Rats. Asian J Biochem 6: 171-180.

34. Korhonen, H and Pihlanto, A. (2001). Food-derived bioactive peptides opportunities for designing future foods. Curr Pharm 9: $1297-1308$.

35. Kubota N., Tobe, K., Terauchi, Y., Eto, K., Yamauchi, T., Suzuki, R., Tsubamoto, Y., Komeda, K., Nakano, R., Miki, H., Satoh, S., Sekihara, H., Saciacchitano, S., Lesniak, M., Aizawa, S., Naqai, R., Kimura, S., Akanuma, Y., Taylor, S.I and Kadowaki, T. (2000). Disruption of insulin receptor substrate 2 causes type 2 diabetes because of liver insulin resistance and lack of compensatory beta-cell hyperplasia. Diabetes 49:1880-1889.

36. Laila, Y.A., Dost, M.H., Abdul, M.A., Yasmine, M and Rana, Z. (2015). Behavioral benefits of camel milk in subjects with autism spectrum disorder. J of the College of Physicians and Surgeons Pakistan 25: 819-823.

37. Malik, A., Al-Senaidy, A., Skrzypczak-Jankun, E and Jankun, J. (2012). A study of the anti-diabetic agents of camel milk. Int J Mol Med 30: 585-592.

38. Martha, S., Veldandi, U.K., Devarakonda, K.R., Pantam, N., Thungathurthi, S and Reddy Yellu, N. (2009). Protective effect of aspirin in relation to IGF-1 in streptozotocin induced type-II diabetic rats. Int J Endocrinol Metab 1: $20-25$.

39. Mazen, A and John, E.G. (2015). Hypoglycemia in patients with diabetes and renal disease. J Clin Med 4: $948-964$.

40. Merecz, A., Markiewicz, L., Sliwinska, A., Kosmalski, M., Kasznicki, J., Drzewoski, J and Majsterek, I. (2015). Analysis of oxidative DNA damage and its repair in Polish patients with diabetes mellitus type 2: Role in pathogenesis of diabetic neuropathy. Advances in Medical Sciences 60: 220-230. 


\section{Mansour et al., Afr J Tradit Complement Altern Med., (2017) 14 (4): 108-119 \\ https://doi.org/10.21010/ajtcam.v14i4.13}

41. Michael, F and Deborah, B. (2001). The effects of metformin on body mass index and glucose tolerance in obese adolescents with fasting hyperinsulinemia and a family history of type 2 diabetes. Pediatrics 107: 1-7.

42. Mima, A., Arai, H., Matsubara, T., Abe, H., Nagai, K., Tamura, Y., Torikoshi, K., Araki, M., Kanamori, H., Takahashi, T., Tominaga, T., Matsuura, M., Iehara, N., Fukatsu, A., Kita, T and Doi, T. (2008). Urinary Smad1 is a novel marker to predict later onset of mesangial matrix expansion in diabetic nephropathy. Diabetes 57: 1712-1722.

43. Mohamad, R.H., Zekry, Z.K., Al-Mehdar, H.A., Salama, O., El-Shaieb, S.E., El-Basmy, A.A., Al-Said, M.G and Sharawy, S.M. (2009). Camel milk as an adjuvant therapy for the treatment of type 1 diabetes: verification of a traditional ethnomedical practice. J Med Food 12: 461-465.

44. Muhammad, Z and Syed, N.N. (2010). Effects of STZ-induced diabetes on the relative weights of kidney, liver and Pancreas in albino rats: A Comparative Study. Int J Morphol 28: 135-142.

45. O'Brien, R.M and Granner, D.K. (1990). PEPCK gene as model of inhibitory effects of insulin on gene transcription. Diabetes Care 13: 327-339.

46. Quinn, P.G and Yeagley, D. (2005). Insulin regulation of PEPCK gene expression: a model for rapid and reversible modulation. Curr Drug Targets Immune Endocr Metabol Disord 5: 423-37.

47. Saleh, O.M., Awad, N.S., Soliman, M.M., Mansour, A.A and Nassan, M.A. (2016). Insulin-mimetic activity of stevioside on diabetic rats: biochemical, molecular and histopathological study. Afr J Tradit Complement Altern Med 13: $156-163$.

48. Sboui, A., Khorchani, T., Djegham, M., Agrebi, A., Elhatmi, H and Belhadj, O. (2010). Antidiabetic effect of camel milk in alloxan-induced diabetic dogs: a dose-response experiment. J Anim Physiol Anim Nutr 94: 540-546.

49. Sharma, R., Yadav, R, and Manivannan, E. (2012). Study of effect of Stevia rebaudiana bertoni on oxidative stress in type2 diabetic rat models. Biomed Aging Pathol 2: 126-131.

50. Soliman, M.M., Hassan, M.Y., Mostafa, S.A., Ali, H.A and Saleh, O.M. (2015). Protective effects of camel milk against pathogenicity induced by Escherichia coli and Staphylococcus aureus in Wistar rats. Mol Med Rep 12(6):8306-12.

51. Srinivasan, K and Ramarao, P. (2007). Animal models in type 2 diabetes research: An overview. Indian J Med Res 125: 451-472.

52. Stenbit, A.E., Tsao, T.S., Li, J., Burcelin, R., Geenen, D.L., Factor, S.M., Houseknecht, K., Katz, E.B and Charron, M.J. (1997). GLUT4 heterozygous knockout mice develop muscle insulin resistance and diabetes. Nat Med 3: $1096-1101$.

53. Velioglu Ogünç, A., Manukyan, M., Cingi, A., Eksioglu-Demiralp, E., Ozdemir Aktan, A and Süha Yalçin, A. (2008). Dietary whey supplementation in experimental models of wound healing. Int. J. Vitam. Nutr. Res., 78(2):70-73.

54. WHO (World Health Organization) report. (2011). Use of glycated haemoglobin (HbA1c) in the diagnosis of diabetes mellitus.

55. Yamada, K and Tanaka, T. (1999). Nutrient and hormonal regulation of pyruvate kinase gene expression. Biochem J 337: $1-11$.

56. Yuuki, A., Kazuya, Y., Toyoaki, W., Vincent, W.K and Tamio, N. (2003). Insulin stimulates expression of the pyruvate kinase $\mathrm{M}$ gene in 3T3-L1 adipocytes. Biosci Biotechnol Biochem 67: 1272-1277.

57. Zagòrski, O., Maman, A., Yafee, A., Meisles, A., van Creveld, C and Yagil, R. (1998). Insulin in milk - a comparative study. Int J Anim Sci 13: 241-244.

58. Zeineb, J., Jean-Michel, G., Isabelle, A., Nadia, O., Pascal, D., Touhami, K and Halima, E.H. (2014). Antioxidant activity of camel milk casein before and after in vitro simulated enzymatic digestion. Mljekarstvo 64: 287-294. 